\title{
International Kinship Care Arrangement: Ethiopian Children Applying for Australian Orphan Relative Visa
}

\author{
Asnakech Tesfaye ${ }^{*}$ and Ashenafi Hagos ${ }^{\dagger}$
}

\begin{abstract}
The study is about international kinship care arrangements in Ethiopia, focusing on Ethiopian children who applied for an Australian Orphan Relative Visa. A qualitative case study research method was used. Study participants were nine children between the ages of 13-17 years and nine parents/guardians of those children. Other participants were five experts from the Ministry of Women, Children and Youth Affairs, and Federal First Instance Court. In-depth interviews were conducted using semi-structured interview guides. Additional data were also derived from observations and document reviews. Thematic data analysis was used. Data from all sources were triangulated and categorized under the themes that emerged from the data. This study identified two categories of children: those who cannot get proper care either due to the loss of parents or due to incapacity of parents to take care of them, and those children who use international kinship arrangement as a mechanism to access a better life in Australia. Children expressed their expectations to get a better education, employment, material benefits, and living conditions after placement abroad. They also expressed concerns about how well relatives abroad will treat them. The findings further revealed that the Ministry of Women, Children, and Youth Affairs was not appropriately documenting pre-placement and post-placement information. Since international kinship care is different from international adoption in its nature, there was a lack of clarity on the legal protection that should be given to children, which puts them in a precarious socio-legal situation. This study can be used as a starting point to understand and consider international kinship care arrangements as one important alternative child care option.
\end{abstract}

Keywords: alternative child care, Ethiopia, kinship care, international kinship care arrangement, orphan relative visa

DOI: https://dx.doi.org/10.1314/ejossah.v16i1.3

\footnotetext{
*Project Manager, Helvetas Swiss Intercooperation, Email: asnimalda@yahoo.com, Tel. : +251927900614, P.O. Box: 27507/1000, Addis Ababa

${ }^{\dagger}$ Corresponding Author: Assistant Professor, School of Social Work, College of Social Sciences, Addis Ababa University, Email: ashenafi.hogos@aau.edu.et and ashehagos@yahoo.com, Tel. : +251911099888, P.O. Box: 1176/ Addis Ababa
} 


\section{Background}

Millions of children around the world are without or at risk of losing parental care due to different reasons. Children face significant challenges in their daily lives, which affect them through their adulthood. In 2015, globally, there were 140 million orphan children, of which 52 million were in Africa (UNICEF, 2017). In developing countries, a large number of children from birth to 5 years of age are not living with their parents. Most children in developing countries, who are not living with their parents, are living with relatives, especially with grandparents (Leigh, 1982, \& Bruskas, 2008). Over 90\% of Orphans and Vulnerable Children (OVC) in developing countries are taken care of by extended families (Biemba, Beard, Brooks, Bresnahan \& Flynn, 2010). Among the extended families who are taking care of OVC, many assume the responsibility without enough financial capabilities (Cudjoe, Abdullah \& Chiu, 2019). In Ethiopia, about 36 million children were deprived of basic services and live in poverty (CSA \& UNICEF, 2019).

Globally several studies have been conducted on various dimensions of child care arrangements and the consequent outcomes, including their education, child-parent relationship, alternative child care, policy, and legal frameworks. Of the existing studies, Manful and Cudjoe (2018) indicated that the living families of relatives are taking the lion share of responsibilities to take care of vulnerable children in developing countries. Most children who are unable to live with their parents are living in a family of relatives, especially grandparents. The number of orphans in developing countries was estimated to be 145 million in the year 2010 (Biemba et al., 2010). These children were taken care of by their extended family members. Moreover, even when one or both parents are alive, a fair number of vulnerable children still live with other members of the extended family. According to Wettasinghe, Shanmugam, and Emmanuel (2012), in Sri Lanka, the general alternative caregiving norms in the households without parental care are mainly permissive of children dropping out of school, child labor, alcohol consumption, sexual conduct at a young age, and allow the early marriage.

Bruskas (2008) study demonstrated that most children in foster care experience feelings of confusion, fear, apprehension of the unknown, loss, sadness, anxiety, and stress. Such experiences might affect such children's social, mental, psychological, and educational developments. Later this negatively affects such children's adulthood life. Zima, Bussing, Freeman, Yang, Belin, and Forness (2000) examined the behavior problems in school-aged children living in foster care. The findings of this study illustrated the prevalence of a high percentage of behavior problems observed among such children in their classrooms. Severe 
delays in reading or math, repeating grades, history of school suspension, and expulsion among school-aged children in foster care were highly prevalent. For example, orphan children in Malawi were less likely to be at school than other children (Hampshire, Porter, Agblorti, Robson, Munthali \& Abane, 2015).

According to Hong, Algood, Chiu, and Lee (2011), since the mid-1990s, government policy in child welfare has become increasingly supportive of familyof-origin or kin-based alternatives for orphan and vulnerable children. The study attempted to show the many benefits associated with kinship-based foster care. The advantages, among others, include increased contact with biological families, preservation of culture, absence of stigma as foster care children, and comfort of being with members of the family. According to Wu, White, and Coleman (2015), older children in kinship care as compared to non-kinship care children showed lower levels of problematic behaviors in the USA. For African children, kinship care is the most sustainable and affordable child care alternative in the absence of parental care (Ariyo, Mortelmans \& Wouters, 2018).

In the Ethiopian context, there are limited studies available on the issues of alternative caregiving for OVC. According to Yohannes (2006), HIV/AIDS and poverty were the main factors that attributed to the severe problems of OVC. This study reported that OVC in west Gojjam was taken care of by their extended families and local HIV/AIDS projects. Meseret (2011) studied the issue of kinship care for OVC in Ethiopia. Her study identified that most kin caregivers were females and live on less than two US Dollars per day. Living arrangement patterns, parents' inability to care for their children because of HIV/AIDS, family expectations, prior relationships with deceased neighbors, and not wanting to send children to the rural area were the major pathways that led kin caregivers to assume the caregiving role. This study also demonstrated that supports provided for kin caregivers were found to be significantly inadequate and irregular and lack consistency.

The Ethiopian government has responded to the situation of OVC by putting in place various alternative care arrangements. The notion of alternative care for children is defined as all residential care (either formal or informal) provided outside of the parental home (Biemba et al., 2010). Ethiopia has developed an Alternative Childcare Guideline (ACG) in 2009. The guideline identified community-based child care, reintegration and reunification, foster care, adoption, and institutional care services as alternative care options for OVC (Ministry of Women and Children Affairs [MoWCA], 2009).

Kinship Care Arrangement (KCA) is one of the various community based alternative child care options available for OVC. KCA can also be arranged across 
international borders. It occurs when children are placed with their relatives living in another country (International Social Service Australia [ISS-Australia], 2011). A larger number of Ethiopian children travel across international boundaries seeking kinship care due to different reasons. These include factors such as the death of parents or guardians, family violence, abuse, neglect, or the inability of parents to provide care for their children, conflict, war, and natural disaster (ISS-Australia, 2013). According to ISS-Australia (2013), a healthy relative who is 21 years old and above have the ability and interest to take care of the child and can both demonstrate his/her ability to provide a safe living environment for the child and assume the role of a guardian through international KCA. However, the person is not required to adopt the child.

Regarding children in need of cross border protections, the UN Guideline for Alternative Care (2010) stated that states concerned should ensure a designated body which has responsibility for determining specific standards to be met. These criteria are used for selecting careers in the host country and the quality of care, as well as for supervising and monitoring the operation of such care arrangements.

To summarize, even though numerous studies have been conducted on alternative child care, very few studies have been conducted on international kinship care arrangements. The existing studies on international kinship care arrangements for orphan and vulnerable children, which are discussed above, were conducted in the western countries. The available Ethiopian literature also made their central focuses on domestic kinship care, foster care, and domestic and international adoptions. But none of them have focused on international kinship care as an alternative childcare arrangement available for orphan and vulnerable children. Thus, this article sought to fill one of the existing gaps by exploring international kinship care arrangements in Ethiopia with a specific focus on Ethiopian orphan and vulnerable children who applied for an Australian Orphan Relative Visa (AORV). More specifically, the study explored the reasons that lead Ethiopian children to apply for AORV, their expectations from being placed in such arrangement, availability of pre-placement supports, and the legal basis in processing international kinship care arrangements in Ethiopia.

\section{Kinship care}

There are two common types of KCA: informal and formal kinship care. Informal kinship care (private kinship care) is an arrangement that is usually made by the family and extended family without child welfare agencies' involvement. Conversely, formal kinship care is organized by statutory authorities as a result of 
the necessity for a child to be placed out of the home (Strozier \& Krisman, 2007; Carpenter \& Clyman, 2004; Winokur, Crawford, Longobardi \& Valentine, 2008).

There are several benefits why kinship care is the most preferred option for providing parental support to children who are in a very difficult circumstance. Kinship care is believed to preserve continuing contact with the birth family, siblings, and extended family networks to help maintain children in the same cultural and ethnic identity. Additionally, it is believed that it decreases the trauma and distress of relocation and grief of separation of a child from his/her biological parents (UNICEF, 2011). For example, in Ghana, kinship care is still playing an important role in providing support for children. However, some kinship care providers need to be supported to provide better care and support for children (Manful \& Cudjoe, 2018).

Since the mid-1990s, the world's government policies in child welfare has become increasingly supportive of family-of-origin or kin-based alternatives for orphan and vulnerable children. Kinship care has become the most preferable alternative care arrangements for OVC. This can be associated with the several benefits that kinship group members can provide for OVC, such as staying in the family of origin (Hong, et al., 2011). According to Cudjoe et al. (2019), kinship care is important to keep children in their comfort zone.

Kinship care does not necessarily assure the well-being of children. Often in Africa, the blood relationship between the caretaker and the child in kinship care is important besides their socioeconomic status (Ariyo, et al., 2018). In African countries, relatives often assume the role of kinship care in the absence of parents. However, since they might assume the responsibilities without having financial capacity the government should involve in different capacities to ensure the wellbeing of children in their kinship settings (Cudjoe et al., 2019).

In Africa, kinship care practices were and are still very common. In many societies, child fosterage is an accepted means of raising children, and members of society value the parenting roles and responsibilities of extended family members in providing parental support for OVC (Chirwa, 2002). Several factors influence kinship care arrangements in most African countries. It includes a wide range of traditional socio-cultural and religious benefits and practices. These factors promote kinship care; family poverty; family breakdown (divorce, re-marriage, early marriage, alcoholism); poor health, death of a parent, HIV, and AIDS or outbreak of other diseases; lack of access to schools, health services or livelihood opportunities; political insecurity, conflict, and disasters; and urbanization and migration (Save the Children, 2015). 
In Ethiopia, as in most traditional societies, a strong norm and values of caring for orphans, the sick, disabled, and other disadvantaged individuals by their extended family members, churches, and mosques have existed for centuries. Based on socio-cultural and religious beliefs, the provision of care to orphaned, abandoned, and vulnerable children have been seen as the duty of the extended family system among most of the ethnic groups in the country (FHI, 2010). In Ethiopia, about one in every five households has a foster child, one in every ten households has a child with only one living parent, and children who lost both of their parents were prevalent in 1 in 100 of the households (The Ethiopian Demographic and Health Survey, 2011).

\section{International kinship care arrangement}

International kinship care arrangement is a child care arrangement where a child is relocated or moved to live and cared for by a relative in another country. International kinship care placements may occur in a neighboring country in the same region or on the other side of the world. Consequently, a child may remain in a similar cultural and linguistic environment or experience a radical shift to a foreign language and an unfamiliar culture. Therefore, the norms of kinship care may vary according to culture, traditions, concepts of family, religion, and the socio-economic status of families involved (ISS, 2013).

Similar to the domestic kinship care arrangements, international kinship care can be arranged formally, a statutory arrangement with the involvement of government child protection agencies and courts or informally; non-statutory arrangement, without the involvement of the state's child protection authorities (ISS, 2013). However, UNICEF (2004) noted that international kinship care arrangement is most commonly arranged on an informal basis.

Hundreds of children are placed with families overseas every year. It holds for a larger number of Ethiopian children who travel across international boundaries. Among Ethiopian children traveling abroad in kinship care, this study focused on children who applied to travel to Australia. Ethiopia has been ranked second among the top ten countries of birth of children and, young people granted Australian orphan relative visas between 2002 and 2012 (ISS, 2013).

Considering the existing gap in the literature, this study aimed to illuminate the state of International Kinship Care arrangements for orphan and vulnerable children, considering the case of Ethiopian children who applied for an Australian orphan relative visa. Hence, it explored the main reasons, children's expectations, the pre-placement supports, and Ethiopian legal provisions and policies concerning international kinship care arrangements. 


\section{Research design}

To get a holistic and in-depth understanding of international kinship care arrangements in Ethiopia qualitative research method was utilized. A case study was employed to get a holistic and in-depth understanding of international kinship care arrangements in Ethiopia. The qualitative research method helps researchers to gain a rich and complex understanding of a specific social context (Mack et al., 2005). Among the qualitative research methods, the descriptive case study design was used since it is appropriate to provide a comprehensive summary of an event (Colorafi, \& Evans, 2016). The qualitative descriptive study helps researchers to stay close to their data (Sandelowski, 2000). In this article, collection methods: indepth interviews, key informant interviews, observations, and document reviews were used to generate data.

Study participants were selected using purposive sampling. The study participants were children who apply for an Australian orphan relative visa. Nine children (13-17 years of age) who (1) had the approval of the court that they can be placed in international kinship care arrangement, (2) were sponsored to live in Australia by a family member, or relative already settled in there, (3) were applying for Australian orphan relative visa by the time of data collection and (4) were willing to participate in the research. The second groups were parents or current caregivers of children (nine) who (1) were providing care to the child who applied for an Australian orphan relative visa at the time of data collection, (2) had been providing care for the child for at least six months prior the interview, (3) had children residing in their homes and (4) were able to communicate clearly in Amharic and (5) were volunteer to speak about their experiences. The number of sampled children and their guardians in this study was determined by theoretical data saturation. Mack (2005) confirms that qualitative study sample sizes are often determined based on theoretical saturation, where the point in data collection no longer brings new data and additional insights into the research questions. However, Nixon and Wild (2012) noted data saturation is regularly achieved, within ten individual interviews, with evidence that this can be achieved, with fewer participants for homogeneous participants.

One judge and two social workers from Bole First Instance Court and two Child Protection and Promotion Experts from the Ministry of Children and Women Affairs participated in the key informant interviews. Criteria used to recruit key informants were: (1) those who have been working on international kinship care arrangement cases for at least a year and a half (2) and those who were willing to participate in the study. 
As the study participants were children and can't decide on their own to participate in the interviews, consents were secured from their parents and caregivers. Parents/caregivers were told about the rights to obtain clear and complete information about the purpose and characteristics of the research. They were also informed about the right to withdraw or decline to participate in the research even after signing the informed consent. Moreover, children had also signed the assent forms. Parents and informants who participated in key informant interviews were also signed consent forms to show their willingness to participate. Personal identifiers of the study participants were avoided in the study report. Only pseudonyms were used to hide the identities of the participants. Participants were informed that their involvement in the study would not create any risk to their process of kinship care arrangement. Information provided by participants was kept in a safe place where they can only be accessed by the researchers. Participation in this research didn't have immediate benefits, such as payments.

The interview questions presented to children were in simple terms and a form of storytelling. Each interview with children took 37 to 42 minutes. With parents, the interview lasted for 44 to 57 minutes, and with key informants, it took from 39 to 64 minutes. Children were interviewed in their respective homes, while parents observing them from distance, without listening to the conversation. Like that of children, parents were also interviewed in their homes while key informants were interviewed in their offices. The interview places were decided by the participants themselves. The interviews carried out with the participants of the study focused on three main issues: (1) reasons that led children to apply for Australian orphan relative visa, (2) children's expectations from their placement in Australia, and (3) the availability of pre-placement supports for them in Ethiopia. Interviews with key informants also answered two main issues; availability of preplacement supports in concerned organizations and the available legal grounds in placing children in international kinship care arrangements. The interview was conducted in Amharic with the use of a tape recorder after securing the participant's written consent.

Observation served as an additional technique that complements the information obtained through interviews and document review. Children's living conditions, their interactions with parents or caregivers, children's reactions to their placement while attending court procedures were critically observed using a check-list developed in a manner that the items were consistent with the research questions. Document review was also used to supply pieces of information that helped explain social practices (Yin, 2003). Thus, such documents as organizational records (individual case reports, court decisions, and application 
packages) were reviewed. Moreover, domestic and international legal principles, guidelines, and conventions concerning international kinship care arrangements and reports on different seminars and workshops were consulted as scrupulously as possible. Similarly, case files from the Ministry of Children and Women Affairs and Federal First Instance Court were critically scrutinized and analyzed in a manner that helps to answer the research question.

Data analysis started with transcribing each interview. An in-depth interview taped using a voice recorder, and a note was also taken. The voices and responses of participants recorded during the interview were transcribed. The noted data was translated into English. The list of possible themes was developed based on the data obtained from children. These themes were polished based on the data obtained from other sources. Themes were developed manually by categorizing conceptually similar stories together as it was recommended by Colorafi and Evans (2016). The preliminary themes were initially developed by one of the researchers, and then discussion had been made with the other researcher where modifications and adjustments were made considering the available data. During the discussion, overlaps were revised and missing themes were added. The researchers wrote their memos and notes under each theme, so they utilized them while writing the research report. The final major themes were: kinship care arrangement, reasons to apply for international kinship care arrangement - permanent loss of parental care, the inability of parents to take care of children, lack of satisfaction and looking for help, and taking over family responsibilities - and expectation from international kinship care arrangement. Data from all participants were categorized under the aforementioned themes. These major themes become headings to present the results. During the write-up of the report, sentences and paragraphs were taken from the transcript to provide pieces of evidence and to enable readers to make their interpretation as it was recommended by Koch, Niesz, and McCarthy (2018).

This study is limited to the state of international kinship care arrangements for orphan and vulnerable children in Ethiopia. The study also covered the experiences of Ethiopian children who apply for an Australian orphan relative visa. Regarding issues included in this study, the study limited its scope at exploring the reasons that lead children to apply for Australian orphan relative visa, children's expectations from their placement with relatives in Australia, the availability of pre-placement supports, and the legal bases in processing international kinship care arrangement in Ethiopia. The study did not include children who apply for international kinship care arrangements in other countries. Though available parents and current caregivers were included, relatives who are sponsoring children were not included in the study. 


\section{Findings}

\section{Participants' background}

The first groups of participants were nine children (four females and five males). Their ages were from 13 to 17 years. In their educational background, four of them were grade 8, two grade 10, and the rest three were in grades 6, 7, and 9, respectively. Among these children, two of them were double orphans, three halforphans, and the remaining four were living with their poor biological parents. Moreover, five biological parents, one uncle, one aunt, and two not close relatives took part in the study as a parent/guardian. The parent/guardian ages were from 37 to 56 years. When we look at the key informant participants, three were working in the Federal First Instant Court (one judge and two social workers) and the remaining two in the Ministry of Women and Children Affairs (MoWCA) as child protection and promotion experts. The work experience of the key informants was from two to four years.

\section{Understanding international kinship care arrangement}

While kinship care is the most common form of out-of-home care in Ethiopia, it is also the type of care least recorded, monitored, or supported. Confusion exists in identifying international kinship care arrangements as a different form of arrangement from other alternative childcare options. Besides this, participants argued that a lack of clarity around specific standards, processes, and responsibilities regarding a child placed with relatives abroad impacted a clear understanding of international kinship care arrangement. Solomon, an expert from MoWCA explained this situation as follows:

Many people, even in our organization, have difficulty understanding the difference between international kinship care arrangement and international relative adoption. It is because the organization used to work more on inter-country adoption than any other type of alternative care options. Besides this, the issue is left open as the arrangement almost entirely depends on private interests.

Most of the Ethiopian community considers taking care of vulnerable relatives as a family obligation rather than simple responsibility. As a result, people never refuse to provide support for their relatives back home even when they live miles away from them. One form of helping families, as identified in this study, therefore, was by placing children in an international kinship care 
arrangement. These deep-rooted socio-cultural norms magnify the importance of international kinship care arrangement as it makes taking care of a relative's child a family obligation. Henok, an expert from MoWCA pointed out this idea as follows:

This kind of arrangement is safe for children because children are staying with their relatives and in their culture. Furthermore, the Ethiopian community has a deep-rooted culture of supporting vulnerable children, especially in the form of kinship caregiving. Relatives are believed not to cause any harm to children they are taking from here.

It is difficult to know how many children today are living in an international kinship care arrangement. The only documentation available in MoWCA provides rough estimates on the number of children in private arrangements across international boundaries. This document shows that between the years 2006 and 2013 , a total of 24,677 children were placed in out of home care system across international boundaries. Among these children, 1,999 were placed in private arrangements with relatives living abroad. Because of poor documentation, though, the exact figure and the prevalence of this arrangement remain unknown.

A total of 143 children were said to have applied to be placed in Australia between the years 2008 to 2016. This number includes children who have applied for both intercountry adoption and international kinship care arrangements. Between these years, the number of applications for intercountry adoption was lower than the number of applications for international kinship care arrangements in Australia. More specifically, in the past ten years, between the years 2006-2016, a total of 201 children were placed in international kinship care arrangements in Australia. Solomon, an expert from MoWCA said the following:

There is a huge gap in the documentation, and not all data are available to tell how many children are placed with relatives overseas. We had a well-organized working system for intercountry adoption. We even assessed and documented children's condition after the placement succeeded. However, the system doesn't work that way for international kinship care. It is because the number of children placed in this arrangement is low compared to intercountry adoption, and children preferred to stay with their relatives no matter where. 
Asnakech Tesfaye and Ashenafi Hagos

The informal nature of this type of arrangement and lack of well-organized documentation, and the existing gaps in the system that manages this specific care arrangement have made information untraceable. Any information related to the pre and post-placement situation of children is also nowhere to be found as information is poorly managed or not recorded at all.

\section{Reasons to apply for international kinship care arrangement}

Although the culture of kinship caregiving in the community has intensified the prevalence of international kinship care arrangement, some major root causes make international kinship care arrangement the only option for children. Two major factors stand behind the decision made by parents/relatives to place children in this kind of arrangement. Some arrangements happen because of out-of-control circumstances, and others happen by the choices made expecting specific outcomes from the arrangement. These reasons are presented under four major categories below. These are: losing parental care due to different reasons, the inability of parents to take care of their children, lack of satisfaction, and looking for permanent help and family responsibilities.

\section{Permanent loss of parental care}

The very common reason that leads children to apply for Australian orphan relative visas was a permanent loss of parental care. Participants explained that permanent loss of biological parents made placing children with extended families abroad the only way to survive. These circumstances occur out of control and make alternative care mandatory for such a child. As a result, placements with relatives abroad were used as the only mechanism as these relatives were considered economically capable of providing good parental support for such orphan children. Three specific causes for parental losses were documented in this specific study, namely; losing parents because of death, losing connection with parents due to migration, and family breakdown through a divorce.

\section{Death of parents}

Deaths of biological parents commonly leave children without appropriate parental care, and these circumstances lead some orphan children to be placed with relatives overseas. When the deaths of biological parents happen, the remaining family members search for other alternative care options for children. Alternative options mostly involved searching for guardians within the extended family members. Children are prone to different risks because of the situations they have been through, and families need to protect them from other parenting issues. 
Especially when children lose both of their parents and have a close family member living abroad, placing them with that relative is taken as a priority because relatives overseas were perceived to be in a better economic situation to take care of them. Sixteen-year-old Rahel explained her situation as follows:

Both of my parents passed away. My father died ten years ago from tuberculosis, and my mother followed three years letter. I and my younger sister were very little when both of them died. I even barely remember my dad. After my mother died, my uncle took me and my sister, and we started living with him. Currently, we are living with our uncle, his wife, and their children. My aunt, who is living in Australia, is going to take us because she lives a better life compared to my uncle here.

Losing both biological parents increases the vulnerability of children to different risks and raises a serious concern. As a result, children desperately look for alternative care options within their family networks. However, it was not the only cause that leads children to be placed in international kinship care arrangements. The study identified that even when children have one surviving biological parent, the death of the other parent forces them to be placed with relatives overseas. When the breadwinner of the family dies, the whole family living situation turns upside down as the remaining parent had economically dependent on the deceased. These situations force children to be placed with relatives because relatives are perceived as more capable of providing better care than current care providers. Seventeen-year-old Nathy illustrates this as follows:

I don't know much about my dad. He died when I was five. I live with my mother and my older brother. My mother used to work in a government organization as an accountant until she got very sick and was forced to quit her job. After she left her job, my older brother and I help her, but it is not enough. Most of the income was coming from my father, and his death turned the family life upside down. That is why she is planning to send us to our aunt in Australia.

\section{Family migration}

Children whose parents have migrated across international borders and who have lost contact are also forced to apply for international kinship care arrangements. In many cases, parents who work abroad and/or migrate to secure employment are forced to place their children in the care of family and friends. Children in this kind 
Asnakech Tesfaye and Ashenafi Hagos

of situation are being taken care of by another extended family member in the country. After some time, different reasons cause these family members unable to continue giving care to children. The inability to get the appropriate care from their parents and other extended family members in the country causes children to seek placement with a relative abroad as an option. Zenebech, a grandmother who was in the process of sending her 13-year-old grandchild, explained the situation as follows:

My daughter gave me her child when she went to Kuwait. This girl was eight years old at the time. She used to call me frequently, but after a while, she stopped to call me as she used to before. She told me she changed her workplace and started working by herself. I knew it was illegal and risky, but what could I say to her? After a while, she stopped calling, and we lost our contact. I can't give the appropriate care to this child by myself, so I begged my other daughter to take her to Australia.

The migration of close family members to the developed countries is another determinant factor in seeking this kind of arrangement. These relatives' strong desires to provide children with better opportunities, such as education are identified as one reason that causes children's placement in international kinship care arrangements. In this specific case, it is used as a mechanism of meeting relative's desires to reunite themselves with the rest of the family. The migration of close relatives took a lion's share in initiating children and other family members to seriously consider this kind of arrangement. Fourteen-year-old Kidus illustrated:

Most of our relatives live in foreign countries. My brother, my aunt, my grandmother, and all of my cousins live overseas. I used to be close with them, especially with my grandmother and my brother. They wanted to take me with them, and my grandmother came here to start the application process. I think it is because there is a better place for all of us to live. My aunt told me that it is a very nice place for kids too. I also saw some pictures and watched some videos, and I like the way they live.

\section{Family breakdown}

The other categories of children who apply for Australian orphan relative visas were those children who had their biological parents divorced and found themselves in complex parenting situations. Family breakdowns due to different reasons deprive children of appropriate parental care. Under such circumstances 60 
the family members of the children fail to provide them care often leaving them in a dangerous situation. The inability of parents to sort out a better way of providing appropriate parental care makes placing children with relatives overseas a reasonable option to be considered. Parents place children with relatives overseas when the situation is considered dangerous to children's proper development and when a relative overseas is considered responsible enough to provide better care. Hawi, a sixteen-year-old girl, said the following:

My parents divorced two years ago. Our relatives were trying to bring peace between them since then, but they couldn't do it. I am going to live with my aunt because I don't think my parents are going to make this family work again.

\section{The inability of parents to take care of children}

The inability of parents to provide parental support for their children because of health, economic, and other issues results in children's placement with relatives overseas. When these types of situations happen, international kinship care arrangements are used as an alternative because kinship caregiving is the most culturally appropriate form of care available for children in the community.

\section{Financial inability}

Economic issues were identified as the most determinant factor in different families that raise a concern about the kind of care children should get from their parents. The inability of parents to meet the basic needs of children causes children's placement in international kinship care arrangements. Problems that parents were experiencing to send children to good schools, provide good health care, and fulfilling other basic needs of children were among the very common forms of economic challenges. International kinship care arrangement is used as the last resort because the family's economic issues could not be managed with family resources available in the country.

Economic difficulty experienced by parents also manifested in parent-child relationships. The overwhelming economic burden makes parents unable to understand the psychological and developmental needs of children. Parents were unable to properly manage and treat changes in children's behavior over time as they are busy trying to manage economic issues in the family. As a result, there is a lack of proper treatment and ability to solve problems in children's overall wellbeing, which leads to the placement of children with relatives overseas, hoping for the best treatments. Fifteen-year-old Samson explained his situation as follows: 
My dad died when I was little, and since then, it is my mother who is taking care of me. My mother lives on remittance she receives from my older siblings. She cannot afford anything if they do not give her money. My sister especially helps my mother a lot. She sends money every month. Therefore my sister started the process to take me to the country where she is living.

\section{Health problems}

The other categories of children in this study who had come to apply for international kinship care arrangements are those living with sick parents. The serious health problem of parents leads children to be placed with relatives. Children, who had their parents sick and have a close relative overseas, prefer to be placed with them rather than looking for other options in Ethiopia. Participants had their reasons and justifications for choosing international kinship care arrangements over the other alternatives they could have in Ethiopia.

In general, kin members living overseas are considered capable of providing the best care for children because they were previously engaged in helping the family for a long time. They are also trusted to understand the emotional and developmental needs of children better than anyone else in the family circle. Being placed in developed nations was also perceived as a huge opportunity for children to get access to a better future and exposure to the modern way of life than staying in the country. These three reasons were taken as the main criteria to place children with relatives overseas when their parents had serious health problems that made alternative care arrangements mandatory. Hiwot, a fifteen-year-old girl explained her situation as follows:

My dad has illnesses that had become more serious since a few years back. ... As my father got seriously sick, he started to get worried about my future, and then my uncle in Australia decided to take me. I am not happy about going because I don't want to leave my dad here alone, but it is not up to me to decide.

Lack of satisfaction and looking for help

When it comes to placing children with relatives living abroad, most of the decisions were made by their parents and current caregivers. Parents' unmet wishes of providing a better life for their children; better education, better living condition, and a better future caused children's placement in international kinship care arrangements to become an option. The mismatch between reality and the 
type of care parents wish to provide their children was identified as a major reason that leads parents to place children in such arrangements.

Despite the love and affection parents have for their children, they give them up to relatives wishing to secure the best future for their children. Participants noted that parents are more concerned with their children's future life than the family environment they might end up in. The highly exaggerated images of western life in the community also resulted in children's lack of interest to continue living in Ethiopia. This situation motivated children to share the desire of their parents to send them abroad. It is considered as one way of showing parental love for their children. Kidus illustrates this situation as follows:

My parents think I can lead a better life if I would live with my aunt. They said I can get a better education, and I can be raised with someone who can afford better things. It is mainly economic issues. I think my parents are not happy with what they get from their job, and they think my aunt can afford better than what they do.

Access to better opportunities such as education, employment, and better living conditions was the ultimate goal of the arrangement in this case. These opportunities were considered to pave the way for children's future self-reliance. Once children are provided with these opportunities, they will stand by themselves instead of keep supported by their relatives overseas for the rest of their lives. Forty-three-year-old mother Sintayehu explained the issue as follows:

My sister-in-law helps us a lot. She sends money to cover my kids' expenses but sending money only helps them for now. She can only help them by providing a better opportunity because if the kids are going to stay here, she is going to help them throughout their lifetime. We see people completing college and having a job but still depend on their family economically. I do not want that to happen to my kids. That is why we have decided to send them abroad. I think at least they will be assured of a permanent job and be able to help themselves in the future.

Another way of providing permanent help was in the form of assuring a brighter future for their children. Assuring a better future for children is thought to be achieved by exposing them to better opportunities. Children were believed to be assured better economic security, better job opportunity, and better education if they migrate to developed nations. Especially parents argued that they want to send 
their children abroad because it is there where they believe their children will have a brighter future. Relatives also take children abroad because it is considered a family obligation to help the rest of the family back home. Yeshihareg, a mother who is planning to send her two children to her sister-in-law, explained this as follows:

I used to work in a government organization, but my salary was not enough to go through the month. I don't want my children to be like me in the future. I want them to be at least better than I am. The best way I can assure that is if I send them somewhere else, to a developed nation. They can get a better education and a better job. I am worried about their future. Their aunt can't keep helping them, so once they go there, things will be ok and they will not need other people's help anymore.

Children look for someone who could care for them, especially when unfortunate things happen to them. Looking for sustainable parental care was observed in children who have suffered from multiple local placements and start desperately searching for relatives to look after them. A fourteen-year-old boy Dagne, who is applying for an Australian orphan relative visa to go to his aunt, narrated:

After both of my parents died, my grandmother took me and my brother to her house. After a while, my grandmother died, and we were placed with another relative in the neighborhood. My relative was not happy with us because my little brother likes to play a lot, and he fights with other kids. She was very mad at him all the time, so we were again placed with my aunt here; she lives alone in a small house. My aunt is now about to go to a foreign country. That is why we are going too.

\section{Taking over family responsibilities}

The family's wish to pass responsibilities of parental support to another person caused children to seek placements with their relatives living abroad. These children are expected to take over family responsibilities after the placement took place. Especially children above the age of fourteen were mainly being placed to take care of their families back home because the relative abroad made other priorities in their lives, such as forming their own family. Elyas, who is sending his nephews to his brother, explained: 
I talked to my brother there; he was the only person who is helping the kids. It has been already over 7 years since he has been sending money to them. We agreed that it is tedious that he sends money all the time. ... It is very difficult for him because he has another family to help too. If he can take one of these kids, he will put off some burden from his shoulder.

Having unemployed or dependent family members at home also seems to encourage children to seek placement with relatives to be able to take care of their members of the family. They believe it is crucial to take over this parental responsibility because it is difficult for parent figures to help all family members at the same time. Similarly, the fact that most relatives have other close family members to help also calls the need to pass on their responsibilities to the children they are taking. Nathy explained this situation as follows:

My mother does not have a job because she is sick. My aunt sends money to help us, but it is not enough. If we can go to our aunt's place, then we will help our mother in a better way. The main reason why I am going is to help my mother. I think helping three people is too much for my aunt right now. Once I and my brother get there, we will be able to help my mother.

\section{The expectation from international kinship care placements}

There were three different ways children explained their expectations from placements overseas. Children associated their expectations with the things they have been sent by their relatives, the things they've heard about living in developed nations, and the things they have seen from the movies and social media. Accordingly, relatively better economic sustainability and education opportunity; better-living conditions, and better employment opportunities were identified as the main positive outcomes expected from international kinship care arrangements. On the other hand, children doubted the love and affection they will get from their relatives after the placement.

Better education was the best possible outcome expected by children as it was one of the main reasons why they are put into this arrangement. They explained what kind of education they expect and how they came to know about it. Children were told that they are going to be able to get the best education in Australia. Children in all cases believed that access to better education is at the forefront of their expectations and were hopeful that they will get the best education after the placements. Dawit explained this situation, and he said: 
I am in grade ten, and I want to study computer science. I spend most of my days practicing computer and mobile technologies. The school I am currently going to is a government school. We are over 60 students in the class, and we cannot access computers easily. Most of the computers in the school do not even work. I think I can get a better education if I go abroad. I can go to a better place that gives the kind of education I want to study. Here, it is hard to learn what you want.

Children's expectations about their future economic situation were associated with tangible things. When talking about economic issues, children explained it in terms of shoes, clothes, houses, and electronics they saw in movies and on social media. These expectations also have their roots in the things that relatives send for them, such as money, clothes, pictures, and videos. These things created excitement in children's minds about a possible future. Their expectations were all perfect and exciting when it comes to economic well-being, as they only associated it with materials sent by their relatives. Ruth, a thirteen years old girl, explained:

I can imagine how my life would be like by the things that she sends us and from the pictures and some videos I watched. She sends me nice stuff every time because it is easy to get in their country. If she can send the nice stuff while I am far away, I think she can provide better things if I can go and start living with her. I think they can afford better than my parents, especially economic wise. I can tell this from the things I heard about their way of life. Everybody at home speaks good things about living in Australia.

Children described what difference such an arrangement would make if they grow up with their relatives living abroad. Though children like to stay in their country, they were worried about growing up being less of whom they want to become. Exposure to the developed world was expected to create a better future for children, especially by providing better access to education and better employment opportunities.

Children's expectations of positive things about their future come from the possibility of accessing or gaining these opportunities to become a better person in the future. Children were aware of opportunities available where they are heading and expect their access would create a better future for them. Ruth explained this idea as follows: 
...my cousins told me it is a good place for girls. Girls can be whatever they want in Australia. I want to be something big, but you know, it is difficult for girls here. I want to go to big colleges and be a doctor. If I go there, I am sure I will be a great doctor.

Relatives' previous engagement in the helping process has built strong trust between children and their relatives. The fact that future caregivers are from the extended family members created an expectation of a familiar family environment in the children's mind. Small conversations made over the phone and their stay with relatives while such relatives were on vacation created a rapport between children and their relatives. This situation gives children a way to know what kind of family environment to expect in the future. Children expect positive psychological, emotional, and economic care and support from relatives. Blen, a social worker from the Federal First Instance Court, explained it as follows:

This arrangement is made by people who have contacts previously and already are engaged in helping children. Therefore, the arrangement is easier and does not feel like a sudden situation for children. Children also feel more comfortable when they are placed in an international kinship care arrangement than any other forms of out of home care, since they know with who they are about to be placed with, and they already have contacts.

On the other hand, there were different doubts about relatives' parenting capability. Because relatives left the country long ago, some children are not sure what kind of parent their relatives might be. The other was that children do not know their relative's personalities as they have not contacted them for a long time, or they went to foreign countries when the children were infants. Relationships are limited to phone conversations that might happen two or three times a year and sending money and other items once in a while. These kinds of relationships do not guarantee the best parental care they want from their relatives overseas.

Though children had issues in fully trusting the psychological and emotional support their relatives may offer, they believe their placement would guarantee permanent parental care, which is one of the expected positive outcomes of this arrangement. Besides, relatives are never expected to treat children wrong as they have a family obligation to take care of children. Nathy explained this situation as:

I do not know much about my aunt, but she sounds like a nice person. I met her four years ago, just once when she was here for a 
Asnakech Tesfaye and Ashenafi Hagos

vacation. That was the only time I met her in person. I only know her in pictures and phone calls. Sometimes she calls us, especially around holidays. She talks more with my mother. I hope we will get along well when I go there, but generally, I think she would be good for us. We don't have that much intimacy, but I think we will get intimate after I go there. Besides, she is my aunt, she will not hurt me no matter what. Though I would miss family life and love, all other things will be great.

\section{Discussion}

The international kinship care arrangement in Ethiopia is not a new phenomenon, but it has been practiced in informal ways. The involvement of government authorities in the process is very limited. As a result, the exact number of children living in this arrangement and the extent of its prevalence is unknown. This finding supports the report by UNICEF (2004) and ISS Australia (2013). Both studies found that most international kinship care arrangements have informally taken place and therefore are difficult to regulate.

There is confusion in understanding the distinction between international kinship care arrangement and international relative adoption. In the case of international KCA, the relatives are not expected to adopt the child rather they are expected to demonstrate their kin relationship with the child/children, financial capability, and willingness to take care of the child/children. All child protection and promotion services available in Ethiopia are intended to contribute positively towards the rights of children upheld by the local and international legal documents (UN Alternative Child care Guideline, 2009). However, international KCA is not indicated as an alternative child care option in alternative child care guidelines. Hence, as compared to other child care options, international KCA is not properly recorded, and the pre and post-placement records are not available in MoWCA. Partly they are not recording such information since the child care arrangement is made between relatives, and it might be difficult to trace the whereabouts of the children.

A significant number of Ethiopian children live in international kinship care arrangements in Australia today, and many more are lining up to be placed yet. A similar study by ISS Australia (2013) also identified Ethiopia as the second top country that placed children in this care arrangement in Australia. However, this area is still very poorly managed and poorly recognized in the country. Although a significant number of children live in this out-of-home care system, attention has 
not been paid by the Ethiopian government to set specific standards and guidelines for its proper management.

This study indicates that the increasing number of Ethiopian children placed in international kinship care relates to the number of Ethiopians who migrated to Australia. Relative's strong desire coupled with their familial obligations to help their extended family lead children's placement with a relative in Australia. Children are mostly placed with their relatives who previously engaged in helping them in different ways. Meseret Kassahun (2011) and Biemba et al. (2010) also support these findings. Alternative care and support arrangements in most African countries and Ethiopia mainly come from an extended family. Kinship care is a better option for children in need, and this is also confirmed by Manful et al. (2018).

Lack of satisfaction with the living conditions in Ethiopia is the major factor for placements of Ethiopian children in international kinship care arrangements. Thus, an international kinship care arrangement is used as a mechanism to migrate to Australia. These findings are quite in contrast to the research finding by ISS Australia (2013), which identified that the majority of these children are from countries that experienced the recent or ongoing conflict or unrest, leading to children's placement in Australia. Drawing on the findings of the present study, it can be said that placements in Australia for the majority of Ethiopian children are not caused by conflict or unrest; rather, they are caused by poverty and migrationdriven factors.

The findings of this study indicate that international kinship care is taken as a form of arrangement that is used to continue as children keep emigrating to families in Australia expecting to get in return better education and employment opportunities. ISS Australia (2013) also identified that sponsors emigrate children to provide them with better education and employment. The present study indicates that though positive expectations from placements in developed nations are common, expecting only the positive outcome, especially in situations where formal assessment and monitoring are absent, could be an illusion. However, Cudjoe et al. (2019) believed that kinship care is a very good placement for children since they will remain with someone they are familiar with.

How children experience their placement and whether they feel sufficiently safe is one of the most important indicators of the child protection system's performance. Children are entitled to the right of expressing their views about their placement no matter where and with whom they are being placed. This right is given to children by the United Nations Convention on the Rights of the Child (UNCRC). The document stated that "State parties shall assure to the child who is 
capable of forming his or her views the right to express those views freely in all matters affecting the child" UNCRC, Article 12 (1). Preservation of these rights highly depends on the existing child protection and promotion system in Ethiopia. The findings of this study identified that well proper documentation regarding pre and post-placement is lacking, which consequently neglects this very right of children.

\section{Conclusions}

Our findings indicated that many Ethiopian children were placed in international kinship care arrangements in Australia. Various factors contributed to the increasing number of children in international kinship care arrangements. The interest to migrate to the developed world and relatives' desire to support their extended families are the major factors. Additionally, the pre-existing informal support mechanism in Ethiopia, especially in the form of kinship caregiving, also accelerated the number of children placed with relatives overseas. Western influence established by the importation of materials, money transfers, and the consequent temptations affected children's attitude about life in Australia and created a set of positive expectations. As a result, a considerable number of children use this arrangement to get to relatives who are already settled in foreign countries.

International KCA is important in availing care and support for children who permanently lose their parents, whose parents are alive but unable to take care of them, and for those children who were not able to get proper care and support. International KCA contributes positively to the rights and welfare of children. However, there is no clear definition, description, or criteria regarding what legal procedures could be followed in processing international kinship care arrangements. Though some of the rights of children in international kinship care arrangements are mentioned in different legal documents, preservation of these rights depends on the existing child protection system.

The existing alternative childcare system could greatly benefit from further research on international KCA to clarify the issues to be addressed, to promote kinship care as an option for children deprived of parental care, and to develop better practice standards and guidelines to ensure the protection and well-being of children. This study also provides practitioners with an understanding that could help them reflect upon their practices and service delivery processes. It also indicates the need to make available support more responsive in addressing the 
needs of children and inform service providers of the need to set specific service provision standards and guidelines. These findings can also be used as a starting point to consider international kinship care as part of the alternative child care system. The findings conclude for the need for a well-developed policy alternative to address the issues with children in the international alternative care system. 


\section{References}

Ariyo, E., Mortelmans, D., \& Wouters, E. (2018). The African child in kinship care: A systematic review. Children and Youth Services Review, 98, 178187. Retrieved from: https://doi.org/10.1016/j.childyouth.2018.12.013

Biemba, G., Beard, J., Brooks, B. Bresnahan, M., \& Flynn, D. (2010). The scale, scope, and impact of alternative care for $\mathrm{OVC}$ in developing countries. Boston University: Center for Global Health \& Development.

Bruskas, D. (2008). Children in Foster Care: A vulnerable population at risk. Journal of Child and Adolescent Psychiatric Nursing, 21 (2), 70-77.

Carpenter, S., \& Clyman, R. (2004). The long-term emotional and physical wellbeing of women who have lived in kinship care: Perspectives on Sexual and Reproductive Health. Guttmacher Institute, 34, 55. Retrieved from: http://www.jstor.org

Chirwa, W.C. (2002). Social exclusion and inclusion: Challenges to orphan care in Malawi. Nordic Journal of African Studies, 11(1), 93-113.

Colorafi, K. J., \& Evans, B. (2016). Qualitative descriptive methods in health science research. HERD. 9(4), 16-25. DOI:10.1177/1937586715614171.

CSA, \& UNICEF (2019). For every child. Retrieved from:

https://www.unicef.org/ethiopia/press-releases/nearly-36-million-childrenethiopia-are-poor-and-lack-access-basic-social-services. October 26, 2020.

Cudjoe, E., Abdullah, A., \& Chiu, M.Y.L. (2019). What makes kinship caregivers unprepared for children in their care? Perspectives and experiences from kinship care alumni in Ghana. Children and Youth Services Review, 101, 270-276. Retrieved from:

https://doi.org/10.1016/j.childyouth.2019.04.018

Ethiopian Demographic Health Survey (DHS). (2011). Ethiopia demographic and health survey. Addis Ababa: FDRE Central Statistics Authority.

Hampshire, K., Porter, G., Agblorti, S., Robson, E., Munthali, A., \& Abane, A. (2015). Context matters: Fostering, orphanhood, and schooling in subSaharan Africa. Journal of Biosocial Sciences, 42(2), 141-164. DOI: https://doi.org/10.1017/S0021932014000169

Hong, J. Algood, C. Chiu, Y., \& Lee, S. (2011). An Ecological understanding of kinship foster care in the United States. Journal of Children and Family Studies, 20, 863-872. DOI:10.1007/s.10826-011-9454-3 
International Social Service Australia, (2013). Submission by international social service Australia to the community affairs references committee inquiry into out of home care. Australia.

Koch, L.C., Niesz, T., \& McCarthy, H. (2018). Understanding and reporting qualitative research: An analytical review and recommendations for submitting authors. Rehabilitation Counseling Bulletin, 57(3), 131-143. DIO:10.1177/0034355213502549.

Leigh, G. (1982). Parent-Absent children: A demographic analysis of children and adolescents living apart from their parents. Family Relations, 31, 567-573.

Nixon, A., \& Wild, D. (2012). Methodologies for assessing and demonstrating data saturation in qualitative inquiry supporting patient-reported outcomes research Affiliations. London: Oxford Outcomes Ltd.

Mack, N., Woodsong, C., Macqueen, K., Guest, G., \& Namey, E. (2005). Qualitative research methods: A data collector's Field Guide. North Carolina: Family Health International (FHI).

Manful, E., \& Cudjoe, E. (2018). Is kinship failing? Views on informal support by families in contact with social services in Ghana. Child \& Family Social Work, 23(4), 617-624. Retrieved from: https://doi.org/10.1111/cfs.12452

Meseret Kassahun. (2011). Kinship care for orphans and vulnerable children in Ethiopia: A mixed-methods study of caregiver coping. Chicago: University of Illinois.

Ministry of Health Ethiopia. (2007). Single point HIV/AIDS prevalence in Ethiopia. Addis Ababa, Federal Ministry of Health.

Ministry of Women's and Children Affairs, (2009). Ethiopian alternative child care guideline on Community Based Child Care, Reunification \& Reintegration Program, Foster Care Services. Addis Ababa, Ethiopia

Sandelowski, M. (2000). Focus on research methods. Real qualitative researchers do not count: The use of numbers in qualitative research. Research in Nursing \& Health, 24, 230-240.

Save the Children. (2015). A sense of belonging: Understanding and improving informal alternative care mechanisms to increase the care and protection of children, with a focus on kinship care in East Africa. Nairobi: East Africa Regional Office (EARO). 
Asnakech Tesfaye and Ashenafi Hagos

Strozier, A., \& Krisman, K. (2007). Capturing caregiver data: An examination of kinship care custodial arrangements. Children and youth services review, 29, 226-246.

UN Guideline for Alternative Care. (2010). United Nations General Assembly guideline for the alternative care for children: Resolution adopted by the general assembly. United Nations, 53, 1-23.

UNICEF. (2004 ). The framework for the protection, care, and support of orphans and vulnerable children living in a world with HIV and AIDS. USA: New York.

UNICEF. (2011). Children in informal alternative care (Discussion Paper, UNICEF). Retrieved from: http://www.unicef.org/protection/Informal care discussion paper final.pdf.

UNICEF, (2017). Orphans, UNICEF Press Center. Retrieved from: https://www.unicef.org/media/media 45279.html.

Wettasinghe, K. Shanmugam, G., \& Emmanuel, S. (2012). Alternative caregiving of migrant workers' children.

Retrieved from: http://220.247.212.102/handle/789/119

Winokur, M., Crawford, G., Longobardi, R., \& Valentine, D. (2008). Comparison of children in kinship care and foster care on child welfare outcomes. Families in society. The journal of contemporary social services, 89(3): 338-346.

Wu, Q., White, K.R., \& Coleman, K.L. (2015). Effects of kinship care on behavioral problems by child age: A propensity score analysis. Children and Youth Services Review, 57, 1-8. Retrieved from: https://doi.org/10.1016/j.childyouth.2015.07.020

Yohannes Mekuriaw. (2006). Community response to the provision of care and support for orphans and vulnerable children, constraints, challenges, and opportunities: The case of Chagni town. Addis Ababa University.

Zima, B., Bussing, R., Freeman, S. Yang, X. Belin, T., \& Forness, S. (2000). Kinship. Journal of child and family studies, 9, 87-103. 